\title{
Incidence and Factors Associated with the Switch to the Second Line Antiretroviral Treatment at the Ambulatory Treatment Center (CTA) in Dakar
}

\author{
Ndeye Fatou Ngom-Gueye ${ }^{1,2 *}$, Gilbert Batista ${ }^{1}$, Abdoul Aziz Ndiaye ${ }^{2}$, Assane Diouf ${ }^{3}$, KA. Daye ${ }^{3}$, \\ Alioune Badara Tall ${ }^{2}$, Awa Diouf ${ }^{1}$, Kine Ndiaye1, Makhtar Ndiaga Diop ${ }^{1}$, Mountaga Dia ${ }^{2}$, \\ Cheikh Tacko Diop², Awa Gaye², Cheikh Tidiane Ndour ${ }^{3}$, Moussa Seydi ${ }^{3}$, Lamine Gueye ${ }^{2}$, \\ Bernard Marcel Diop', Papa Salif Sow ${ }^{3}$

\footnotetext{
${ }^{1}$ Ambulatory Treatment Center, Fann University Teaching Hospital, Dakar, Senegal

${ }^{2}$ Department of Community Health, Alioune Diop University, Bambey, Senegal

${ }^{3}$ Department of Infectious Diseases, Fann University Teaching Hospital, Dakar, Senegal

Email: *ndeyetouti98@gmail.com
}

How to cite this paper: Ngom-Gueye, N.F., Batista, G., Ndiaye, A.A., Diouf, A., KA. D., Tall, A.B., Diouf, A., Ndiaye, K., Diop, M.N., DIA, M., Diop, C.T., Gaye, A., Ndour, C.T., Seydi, M., Gueye, L., Diop, B.M. and Sow, P.S. (2016) Incidence and Factors Associated with the Switch to the Second Line Antiretroviral Treatment at the Ambulatory Treatment Center (CTA) in Dakar. Health, 8, 1566-1575.

http://dx.doi.org/10.4236/health.2016.814154

Received: October 21, 2016

Accepted: November 20, 2016

Published: November 23, 2016

Copyright $\odot 2016$ by authors and Scientific Research Publishing Inc. This work is licensed under the Creative Commons Attribution International License (CC BY 4.0).

http://creativecommons.org/licenses/by/4.0/

(c) (i) Open Access

\begin{abstract}
Introduction: Over the past years, efforts have been made to expand access to antiretroviral combinations (cART) in low-income countries. However, major concerns are noted with drug resistance emergence, as treatment failure result and need to introduce a second line treatment, more expensive and difficult to implement. The objective was to study the incidence of switch to second line, reasons for switch and risk factors using a cohort of people living with HIV in an Ambulatory Treatment Center in Dakar. Methodology: This was a cohort study of people living with HIV under cART from January 2004 to December 2013. Naive patients monitored for at least six months, regardless of their profile and regimen with baseline CD4 counts $<350$ cells $/ \mathrm{mm}^{3}$ were included in this study. Results: The median age of the 827 patients included was 44 [IQR $=18-78]$. The switch to second-line treatment was observed in 72 patients $(8.7 \%)$ after an average of 38.5 months of follow-up. The overall incidence rate of switch to second line of antiretroviral treatment was 1.59 per 100 persons-years. Most of changes in first-line treatment were motivated by virological failures $(\mathrm{n}=60,83.3 \%)$ under treatment with AZT/3TC/NVP $(\mathrm{n}=25,34.7 \%)$ or AZT/3TC/EFV21 (29.2\%). 9.7\% of switch occurred after immunological failure, $1.4 \%$ after clinical failure, $4.2 \%$ after severe toxicity and $1.4 \%$ was not documented. Predictive factors identifying failures at the end of the multivariate analysis were age $<44$ years and CD4 counts below 100 cells $/ \mathrm{mm}^{3}$. Conclusions: In total, CTA identified a low incidence rate of treatment failure of the first line of treatment. Associated risk factors were age $<44$ years, CD4 counts below 100 cells $/ \mathrm{mm}^{3}$ and high viral load at treatment initiation.
\end{abstract}




\section{Keywords}

Incidence, Associated Factors, Switch to $2^{\text {nd }}$ Line cART, CTA, Dakar

\section{Introduction}

The majority of people infected with HIV live in Sub-Saharan Africa [1]. In these countries, AIDS-related morbidity and mortality remain the highest in the world due to limited access to diagnosis and treatment of HIV [1]. In recent years, efforts have been made to expand access to antiretroviral combinations (cART) in several low-income countries. In 2012, 9.7 million people have been under ART therapy in low- and middle-income countries [2]. This represents $61 \%$ of those eligible according to the 2010 guidelines of the World Health Organization (WHO) on HIV. In June 2015, only 15.8 million people had access to treatment while over 22 million people were supposed to benefit from antiretroviral therapy [3].

Since 2010 , an increase of $84 \%$ in access to antiretroviral therapy was noted [2]. Short-term observations on the effectiveness of antiretroviral therapy in resource-limited countries show encouraging results [4] [5]. However, major concerns such as the durability of therapeutic response, long-term effect on mortality risk among patients loss to follow-up and the emergence of resistant viral strains ARVs are yet to be addressed. On more or less longer terms, this announces the introduction of a second-line treatment more expensive and difficult to implement [6] [7]. Due to limited access to plasma viral load, a higher number of patients likely to undergo treatment failure have not changed their first-line treatment [8] [9].

This study was therefore conducted to determine the incidence and factors associated with the switch to the second line of antiretroviral combinations at the Ambulatory Treatment Center (CTA) in Dakar.

\section{Method}

We conducted a cohort study among the people living with HIV (PLHIV) under ARV therapy was conducted from January 2004 to December 2013 at the Ambulatory Treatment Center.

Naive patients of any antiretroviral treatment, followed-up for at least six months were included in this study.

Patients with CD4 cell counts $\geq 350$ cells $/ \mathrm{mm}^{3}$ at inclusion, those having benefited from the PMTCT as well as the non-naive of ARV treatment were not included in our study. As part of this study, data were collected based on various factors such as: sociodemographic (age, sex, marital status), clinical (Body Mass Index (BMI), calculated as weight in kilograms divided by the square of the height in meters, the HIV profile, the WHO clinical stage), para clinical (CD4 count, viral load), therapeutic (date of inclusion to treatment, type of first-line treatment, first line treatment change date) and evolution (follow up period, loss of follow up, death, transfer and treatment failure). 
These data were collected from different sources (medical records, social files, database, etc.).

The main interest was the switch to second line, further to treatment failure, which is defined as a virological, or immunological or clinical failure related to severe toxicity or other. The virological failure was defined as HIV RNA levels $>1000$ copies $/ \mathrm{ml}$ after at least 6 months of a well-monitored treatment. Immunological failure was defined as a CD4 count $<100$ cells $/ \mathrm{mm}^{3}$ to all measures available within the specified time range or drop below pretreatment values, or drop in CD4 count less than $50 \%$ of the value of the peak obtained under treatment.

Clinical failure was defined as the presence of persistent or new clinical event belonging to stage 4 of the WHO classification 6 months after the start treatment.

All data were analyzed using Stata version 12. The first step was the description of the study population: its main characteristics (demographic, clinical, paraclinical) for entry into the cohort were grouped in Table 1.

For each continuous variable, the following aspects were specified: median, standard deviation, quantiles including inter quartile range (IQR). The comparison of proportions was performed using the Chi-square test or the Fisher exact test if necessary. The averages were compared using Student $\mathrm{T}$ test and ANOVA. Then, the cumulative incidence of the switch to $2^{\text {nd }}$ line was evaluated using Kaplan Meier curves. The survival time is the period between the ARV treatment of first line and the date of occurrence of treatment failure. For individuals who were not submitted to the second line, the data were censored at the date of latest news (for the loss follow-up, transferred and deceased) or at the date point of 30 June 2014 for PLHIV who were followed-up on a regular basis from that date. For the multivariate analysis, we only considered the variables which had a P-value less than 0.05 in univariate analysis. Cox regression was used to identify factors associated with the treatment failure.

\section{Ethical Aspect}

An anonymous database was compiled from medical and social records of patients at CTA. No information revealing the identity of the patients was included in this study. The database remains a CTA property. The study received prior approval by the head of the Clinic of Infectious Diseases.

\section{Results}

\subsection{Descriptive Study}

\subsubsection{Demographics}

A total of 827 patients were included in this study. The Median age of patients was 44 years with [IQR $=37$ - 51]. We note a predominance of women 528 (63.8\%), patients in union (427) were more representative with a proportion of 53.0\% (married monogamous, polygamous and concubines combined) (see Table 1).

\subsubsection{Clinical Characteristics}

At inclusion, most of patients were at stage $3(36.1 \%)$ or stage $2(32.2 \%)$. Knowing that 
Table 1. Baseline characteristics of the population study.

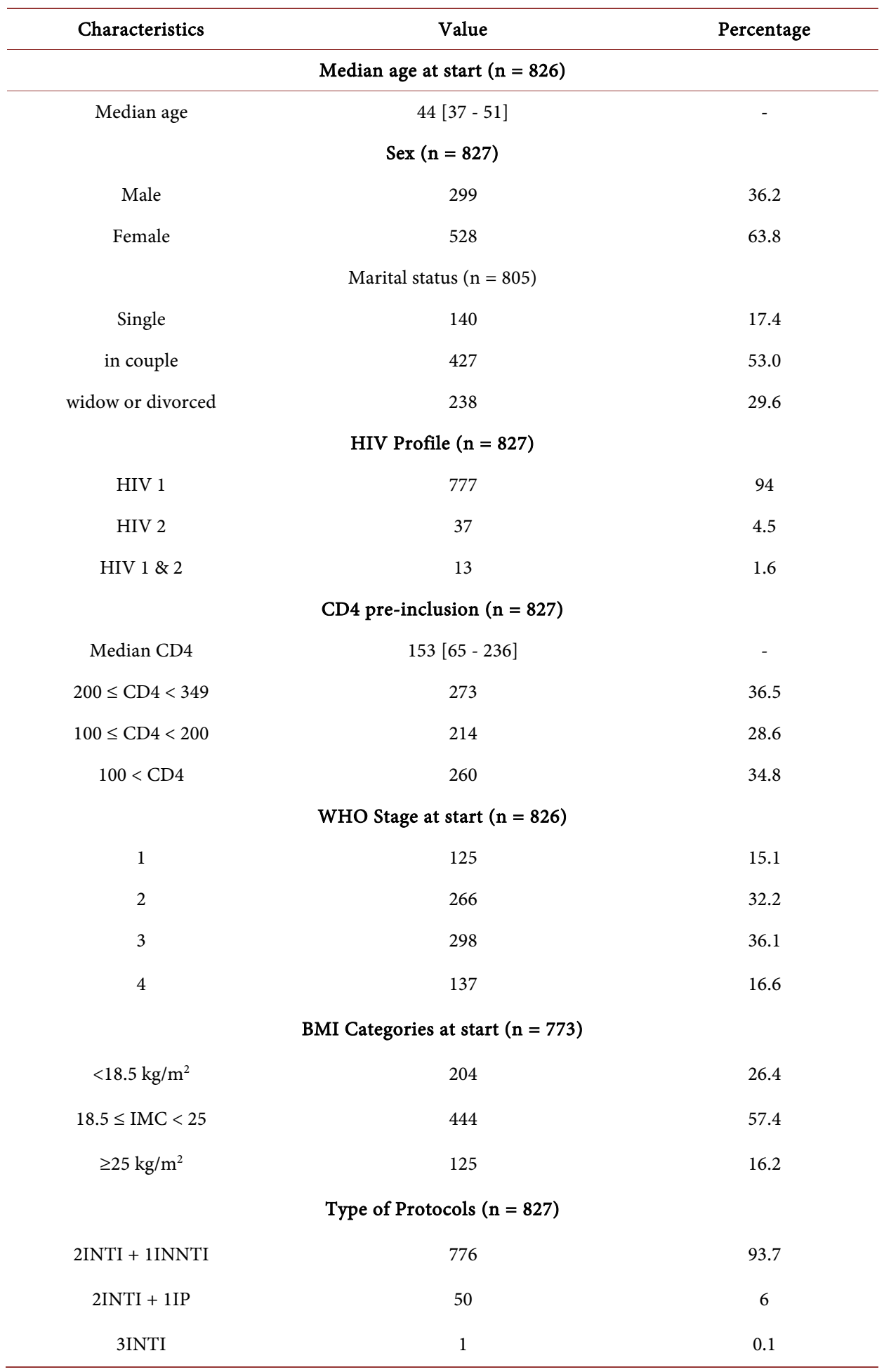

a patient is considered in a state of malnutrition if $\mathrm{BMI}<18.5 \mathrm{~kg} / \mathrm{m}^{2}$, normal if 18.5 $\mathrm{kg} / \mathrm{m}^{2} \leq \mathrm{BMI}<25 \mathrm{~kg} / \mathrm{m}^{2}$, overweight if $25 \mathrm{~kg} / \mathrm{m}^{2}<\mathrm{BMI}<30 \mathrm{~kg} / \mathrm{m}^{2}$ and obese if BMI $\geq$ $30 \mathrm{~kg} / \mathrm{m}^{2}$. At inclusion, $26.4 \%$ of patients were malnourished (see Table 1). 


\subsubsection{Biological Characteristics}

Patients infected with HIV-1 are the majority and represent $94.0 \%(\mathrm{n}=777)$. Of all the 747 patients in the study, the average CD4 count was 153 cells $/ \mathrm{mm}^{3}$ with an interquartile range [65 - 236]. The majority of patients had at baseline CD4 counts between 200 and 350 cells $/ \mathrm{mm}^{3}$ (see Table 1 ).

\subsubsection{Therapeutic Characteristics}

Between 2004 and 2006, 282 (34.1\%) patients were put under ART; from 2007 to 2009, 324 (39.2\%) and from 2010 to 2013, 221 (26.8\%). Of the 827 patients, 776 (93.8\%) had 2 NRTI + 1INNTI as protocol; $50(6 \%)$ were under 2 NRTI + 1IP and one $(0.1 \%)$ was under 3INTI (see Table 1).

\subsubsection{Characteristics of Failure}

Of the 827 patients, $72(8.7 \%)$ were switched to second-line treatment after an average of 38.5 months follow-up (IQR $=26.5$ to 56.5 ). The overall incidence rate of the switch to second line antiretroviral treatment was 1.59 per 100 persons-years.

Most first-line treatment changes were motivated by virological failures 60 (83.3\%) mainly in treatment based on AZT/3TC/NVP25 (34.7\%), AZT/3TC/EFV21 (29.2\%). On the contrary, $9.7 \%$ of immunological failures and $1.4 \%$ of clinical failures were observed. Other than treatment modifications for immunological, virological and clinical failures, $4.2 \%$ of the changes were due to severe drug toxicity. The remaining changes (1.4\%) were not documented

\subsubsection{Progressive Characteristics}

Of the 827 patients, 54 (6.5\%) were lost after an average follow-up of 20.5 months (IQR $=12$ to 34.5 ). During the study period, $4.0 \%$ of patients were transferred. The 24 cases of death (2.9\%) occurred after an average follow up period of 23.5 months (IQR $=12$ $55)$.

\subsection{Analytical Study}

\section{Factors Associated with Failure under Treatment \\ -Univariate analysis:}

We found no significant association between switching to second line ARV treatment and sex, marital status, HIV profile, WHO clinical stage, body mass index (BMI) and the period of inclusion. Only age, CD4 count and viral load at the start of treatment were significantly associated with the switch to the second line (see Table 2).

The probability to remain under first line is higher in elderly patients of at least 44 years, $p=0.03$. Patients with a CD 4 count between 1 and 99 cells $/ \mathrm{mm}^{3}$ at inclusion have experienced more failure compared to those having a CD4 cell count between $100-199$ cells $/ \mathrm{mm}^{3}$ and 200 to 349 cells $/ \mathrm{mm}^{3}$; with $p=0.02$ (Figure 1 and Figure 2).

\section{-Multivariate analysis:}

The final cox model retained, the most accurate, includes the independent variables (age, CD4 Baseline, viral load > 100,000 copies/ml) that were significantly associated with the shift into second line ARV treatment. Patients aged 44 years or older at the 


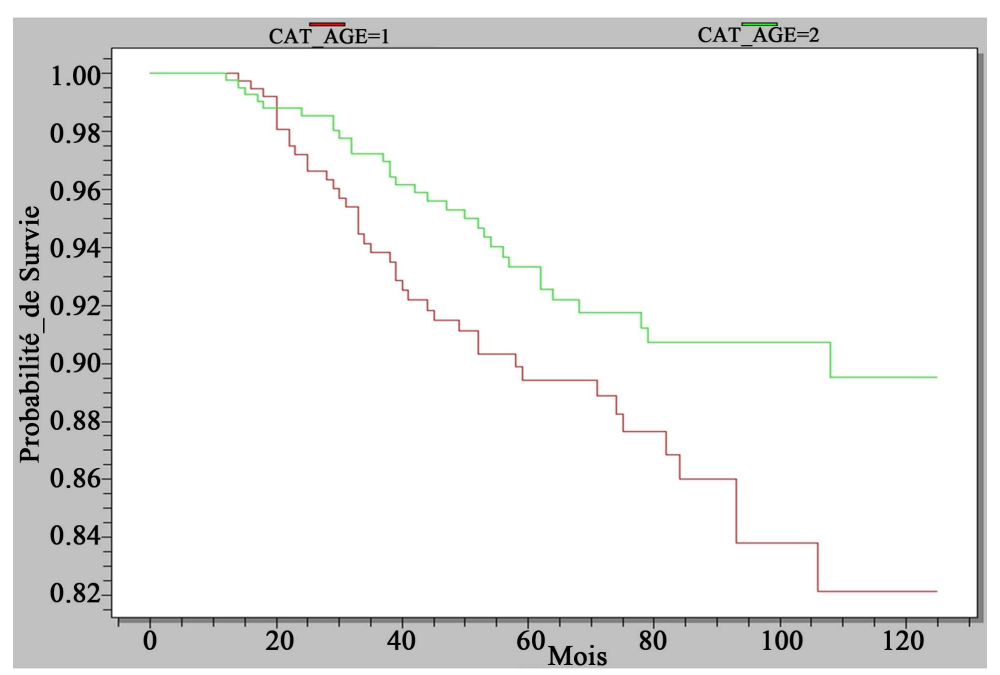

Figure 1. Curves of probability to stay on the first line according to age over time. CAT_AGE 1 shows patients under 44 years.

Table 2. Factors associated with failure under treatment.

\begin{tabular}{|c|c|c|c|c|}
\hline \multirow{2}{*}{$\begin{array}{l}\text { Characteristics } \\
\text { Age (in year) }\end{array}$} & \multicolumn{2}{|c|}{$\begin{array}{l}\text { Univariate Analysis } \\
\text { HR [IC95\%] } P \text {-value }\end{array}$} & \multicolumn{2}{|c|}{$\begin{array}{l}\text { Multivariate Analysis } \\
\text { HR [IC95\%] } P \text {-value }\end{array}$} \\
\hline & & & & \\
\hline$<44$ years & 1 & & 1 & \\
\hline$>44$ years & $0.60[0.37-0.96]$ & 0.033 & $0.56[0.34-0.91]$ & 0.0216 \\
\hline \multicolumn{5}{|l|}{ Sex } \\
\hline Female & 1 & & & \\
\hline Male & $1.34[0.84-2.14]$ & 0.215 & - & \\
\hline \multicolumn{5}{|l|}{ Marital Status } \\
\hline Single & 1 & & & \\
\hline in couple & $1.10[0.59-2.04]$ & 0.764 & - & \\
\hline widow or divorced & $0.66[0.32-1.38]$ & 0.276 & - & \\
\hline \multicolumn{5}{|l|}{ HIV Profile } \\
\hline VIH-1 & 1 & & & \\
\hline VIH-2, VIH-1 + 2 & $0.62[0.19-1.99]$ & 0.423 & - & \\
\hline \multicolumn{5}{|l|}{ WHO Stage at start } \\
\hline 1 or 2 & 1 & & & \\
\hline 3 or 4 & $1.31[0.82-2.10]$ & 0.249 & - & \\
\hline \multicolumn{5}{|l|}{ IMC Categories } \\
\hline$<18.5 \mathrm{~kg} / \mathrm{m}^{2}$ & 1 & & 1 & \\
\hline $18.5 \leq \mathrm{IMC}<25$ & $1.03[0.60-1.74]$ & 0.912 & $1.06[0.61-1 . .85]$ & 0.810 \\
\hline$\geq 25 \mathrm{~kg} / \mathrm{m}^{2}$ & $0.46[0.18-1.15]$ & 0.099 & $0.50[0.18-1.36]$ & 0.178 \\
\hline \multicolumn{5}{|l|}{ CD4 pre-inclusion } \\
\hline $200 \leq \mathrm{CD} 4<349$ & 1 & & 1 & \\
\hline $100 \leq \mathrm{CD} 4<200$ & $1.23[0.63-2.42]$ & 0.533 & $1.10[0.56-2.18]$ & 0.768 \\
\hline$<100$ cells $/ \mathrm{mm}^{3}$ & $2.08[1.16-3.71]$ & 0.013 & $1.85[1.10-3.39]$ & 0.044 \\
\hline \multicolumn{5}{|l|}{ Viral load } \\
\hline$\leq 100,000$ & 1 & & 1 & \\
\hline$>100,000$ & $0.27[0.08-0.9]$ & 0.04 & $0.22[0.06-0.79]$ & 0.02 \\
\hline \multicolumn{5}{|l|}{ Inclusion period } \\
\hline 2004-2006 & 1 & & & \\
\hline 2007-2009 & $1.58[0.93-2.68]$ & 0.08 & - & \\
\hline $2010-2013$ & $0.88[0.36-2.12]$ & 0.78 & & \\
\hline
\end{tabular}




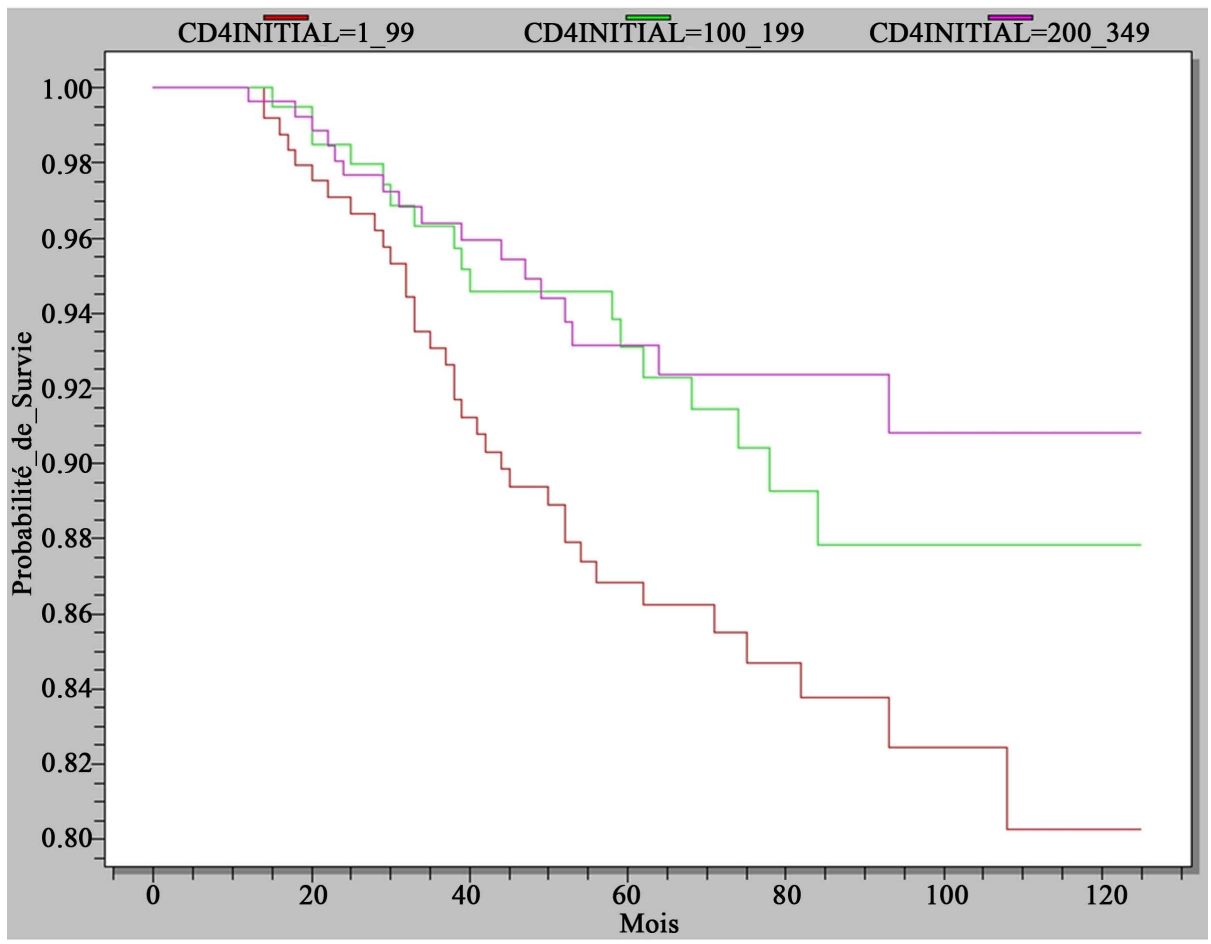

Figure 2. Probability curves to remain on the first lines according to the CD4 count over time.

time of ARV treatment, have a lower risk in second-line passage of less than $44 \%$ compared with patients who were younger than 44 years $(p=0.02)$. Similarly, patients who were very immunodepressed before inclusion to treatment (with a CD4 count $<100$ cells $/ \mathrm{mm}^{3}$ ) were 1.85 times more at risk switched to second line than patients who had moderate immunodepression (CD4 between 200 and 350), $p=0.04$ (see Table 2).

\section{Discussion}

The success of antiretroviral treatment programs in low-income countries is usually associated with free treatment and access to programs [10] [11], cotrimoxazole prophylaxis [10] [11] [12], and active ownership and policy implementation [13] [14]. The use of CD4 count and viral load to monitor the effectiveness of ART reduces the morbidity and the mortality in a context of limited resources [15] and allows making a decision in changing the treatment from the first to second line. In this study, we report an overall incidence rate of the switch to a second line antiretroviral treatment of 1.59 per 100 persons-year on a site dedicated to ambulatory care of persons living with HIV and AIDS in Dakar as well as factors associated with this change. As shown in a study, the incidence rate was 4.9 per 100 persons-year during the first 6 months of treatment. [16]. The CD4 cell count at ART initiation and specifically a CD4 count below 100 cells $/ \mathrm{mm}^{3}$ was independently associated with a risk of line change. Our results confirm those seen in other studies in sub-Saharan Africa (Mozambique, Malawi, Guinea-Conakry) [16], and in South Africa in a large cohort of 19,645 patients [17].

The clinical stage was not a determining factor associated with the risk as reported by 
Leonardo, P et al. that $37.1 \%$ of the cohort were classified as being in stage 3 or 4 [16]. It is then important to note that the patients, most of the time, come at a late stage of the disease in a symptomatic condition. In HIV people under ART, the decision on when to switch to second-line treatment is directly related to the different types of therapeutic failure. In our study, we also report that $83.3 \%$ of the failures were virological and $9.7 \%$ immunological. These results are comparable to the data of Fox et al. [17] but another study found a prevalence of immunological failure of $68.2 \%$ [16]. Overall, these results show that the diagnosis of failure is all the more early as $83.3 \%$ are virological. The shift from the first to the second line must be done as soon as possible, i.e. as soon as virological failure is diagnosed; otherwise, the vital prognosis of patients is at stake.

The highest failure probability in patients under 44 years $(p=0.03)$, confirms the previous report of Henry DM et al made in Cameroon (18 - 29, $p=0.024)$, which may be attributed to the non-observance to treatment [18]. Patients aged 44 years or older at the time of ARV, have a lower risk when switched to second line less than $44 \%$ compared to patients who were under 44 years $(p=0.02)$. Similarly, patients who were very immunodepressed before inclusion to treatment (with a CD4 count $<100$ cells $/ \mathrm{mm}^{3}$ ) were 1.85 times more likely to switch to second line compared to patients who had moderate immunodepression (CD4 between 200 and 350), $p=0.04$. Similar results were reported by Suely $\mathrm{H}$ [19] in Brazil, the failure was associated with younger age (average 34 vs. 37 years, $p=0.003$ ) and CD4 lower at inclusion (86 vs 182, $p=0.006$ ).

\section{Conclusion}

The study revealed a low incidence of treatment failure of the first lines of treatment (1.59 per 100 persons a year). Associated risk factors were age $<44$ years, CD4 counts below 100 cells $/ \mathrm{mm}^{3}$ and high viral load at treatment initiation. This shows that ART programs based on the public health approach using similar patterns in resource-limited countries are as effective as those seen in clinical cohorts in developed countries.

\section{Declaration of Absence of Conflict of Interest}

The authors report no conflict of interest.

\section{Authors' Contributions}

NGOM GUEYE Ndeye Fatou, BATISTA Gilbert, NDIAYE Abdoul Aziz, DIOUF Awa and DIOUF Assane: design, data collection, statistical analysis and manuscript review. Other authors: design and manuscript review. All the authors have read and approved the final version of the manuscript.

\section{References}

[1] World Health Organization (2013) Consolidated Guidelines on the Use of Antiretroviral Drugs for Treating and Preventing HIV Infection: Recommendations for a Public Health Approach. World Health Organization, Geneva.

[2] Rapport ONUSIDA sur l'épidémie mondiale de sida 2013. " ONUSIDA / JC2502/1/F ». 
Classification NLM: WC 503.6 (Consulté le 13/03/2014).

[3] Rapport ONUSIDA sur l'épidémie mondiale de sida 2015.

[4] Vézinet, F.B., Charpentier, C. and Descamps, D. (2011) Résistance aux antirétroviraux Doin édition 2011. Wolters Kluwer France 2011, 461-533.

[5] Praag, E.V. and Vella, S. (2002) Sécurité et efficacité des traitements antirétroviraux chez l'adulte plus particulièrement en situation de ressources limités. OMS, 68 p.

[6] Semaille, C. and Lot, F. (2011) Epidémiologie: Situation actuelle et tendances. Doin VIH édition 2011, Wolters Kluwer France, 49.

[7] Leprêtre, A. and $\mathrm{Ba}$, I. (2011) Enquête de pratiques à risque et de la prévalence des infections VIH et VHC chez les usagers de drogues injectables dans la région de Dakar. ANRS 12243 UDSEN/ICASA 2011.

[8] Diop-Ndiaye, H., et al. (2005) Apport du laboratoire dans le diagnostic et le suivi de l'infection à VIH dans le LP. Le magazine de la pharmacie, nov.-déc., 44.

[9] Katlama, C. and Jade, G. (2008) VIH et SIDA. Prise en charge et suivi du patient. Elsevier Masson.

[10] Hirsch, M.S., Günthard, F.H., Schapiro, J.M., Brown-Vézinet, F., et al. (2008) Antiretroviral Drug Resistance Testing in Adults Infected with Human Immunodeficiency Virus Type 1: Recommendations of International AIDS. Clinical Infectious Diseases, 47, 266-285. https://doi.org/10.1086/589297

[11] Van Heuverswyn, F., Li, Y., Neel, C., Bailes, E. and Keele, B.F. (2006) Human Immune- Deficiency Viruses: SIV Infection in Wild Gorillas. Nature, 444, 164. https://doi.org/10.1038/444164a

[12] Diop-Ndiaye, H., Diallo, S., Kébé, K., Diallo, F., Mboup, M., Kane, M., et al. (2008) Apport du papier filtre dans la prise en charge des patients infectés par le VIH-1 au Sénégal. Xvème ICASA 2008 abstract No. 658/SOA07.

[13] Bartlett, J.-G. (2005) Pocket Guide to Adult HIV/AIDS Treatment Potomac Falls. Johns Hopkins University Aids Service, Baltimore, 80 p.

[14] Erice, A., Mayers, D.L. and Strike, D.G. (1993) Primary Infection with Human Immunodeficiency Virus Resistant Zidovidine Kind. New England Journal of Medicine, 328, 1163 1165. https://doi.org/10.1056/NEJM199304223281605

[15] Katlama, K. (2011) Prise en charge de l'échec du traitement antirétroviral VIH édition 2011. Wolters Kluwer, Alphen aan den Rijn, 432-433.

[16] Palombi, L., Marazzi, M., Guidotti, G., Germano, P., Buonomo, E., Scarcella, P., Altan, A., Magnano, M., Lio, S. and De Luca, A. (2009) Incidence and Predictors of Death, Retention, and Switch to Second-Line Regimens in Antiretroviral-Treated Patients in Sub-Saharan African Sites with Comprehensive Monitoring Availability. Clinical Infectious Diseases, 48, 115-122. https://doi.org/10.1086/593312

[17] Fox, M.P., Cutsem, G.V., Giddy, J., Maskew, M., Keiser, O., Prozesky, H., et al. (2012) Rates and Predictors of Failure of First-Line Antiretroviral Therapy and Switch to Second Line ART in South Africa. Journal of Acquired Immune Deficiency Syndromes, 60, 428-437. https://doi.org/10.1097/QAI.0b013e3182557785

[18] Meriki, H.D., Tufon, K.A., Afegenwi, M.H., Nyindem, B.A., Atanga, P.N., Anong, D.N., Cho-Ngwa, F. and Nkuo Akenji, T. (2014) Immuno-Haematologic and Virologic Responses and Predictors of HIV-1 in Virologic Failure Infected Adults on First-Line in Antiretroviral Therapy in Cameroon. Infectious Diseases of Poverty, 3, 5.

https://doi.org/10.1186/2049-9957-3-5 
[19] Tuboi, H.S., Harrison, L.H., Sprinz, E., Albernaz, R.K. and Schechter, M. (2005) Predictors of Virologic Failure in HIV-1-Infected Patients Starting Highly Active Antiretroviral Therapy in Porto Alegre, Brazil. Journal of Acquired Immune Deficiency Syndromes, 40, 324-328. https://doi.org/10.1097/01.qai.0000182627.28595.01

Submit or recommend next manuscript to SCIRP and we will provide best service for you:

Accepting pre-submission inquiries through Email, Facebook, LinkedIn, Twitter, etc. A wide selection of journals (inclusive of 9 subjects, more than 200 journals)

Providing 24-hour high-quality service

User-friendly online submission system

Fair and swift peer-review system

Efficient typesetting and proofreading procedure

Display of the result of downloads and visits, as well as the number of cited articles

Maximum dissemination of your research work

Submit your manuscript at: http://papersubmission.scirp.org/

Or contact health@scirp.org 